\section{M-mode echocardiography measurements of healthy Brazilian random bred cats}

\author{
Medidas ecocardiográficas em Modo-M de gatos brasileiros sem \\ raça definida
}

Bruno Ricardo Soares Alberigi da Silva** (D), Alexandre José Rodrigues Bendas² (D), Denise do Vale Soares ${ }^{3}$ (D), Carolina Aben Athar ${ }^{1}$ (D), Fabiana Batalha Knackfuss ${ }^{4}$ (D), Renan Salhab Demo ${ }^{5}$ (D), Mateus Fernando Senra Almeida ${ }^{5}$ (i) \& Jonimar Pereira Paiva ${ }^{6+}$ (i)

'Veterinary, doctorate, MSc. Programa de Pós-graduação em Medicina Veterinária - PPGMV, Universidade Federal Rural do Rio de Janeiro - UFRRJ, Seropédica, RJ, Brasil

²Veterinary, doctorate, MSc. Programa de Pós-graduação em Medicina Veterinária (Clínica e Reprodução Animal), Universidade Federal Fluminense - UFF, Niterói, RJ, Brasil

${ }^{3}$ Veterinary. Instituto de Especialidades em Medicina Veterinária - IEMEV, Rio de Janeiro, RJ, Brasil

${ }^{4}$ Zootechnist, MSc, DSc. Universidade do Grande Rio - UNIGRANRIO, Duque de Caxias, RJ, Brasil

${ }^{5}$ Undergraduate students of Veterinary Medicine. Universidade Federal Rural do Rio de Janeiro - UFRRJ, Seropédica, RJ, Brasil

Veterinary, Dr. Departamento de Medicina Veterinária e Cirurgia, Universidade Federal Rural do Rio de Janeiro - UFRRJ, Seropédica, RJ, Brasil

tDeceased

\begin{abstract}
To determine the M-mode echocardiography reference measurements for Brazilian random bred cats in Rio de Janeiro, Brazil, cats presenting for routine care were examined by M-mode echocardiography. Animals with free wall values of the left ventricle and/or interventricular septum above $5 \mathrm{~mm}$ were not included. A total of 125 cats with were included in the study. The correlation of the body score condition (BSC) with the echocardiography measurements was positive for left ventricle wall in systole (LVWs) and left ventricular wall in diastole (LVWd). The LVWd values of BSCs 3 and 4 were different; and those of BSCs 3 and 5 were also different. The LVWs values of BSCs 3 and 5 were different. The correlated effect between BSC and the echocardiography measurements was true for the left atrium, left atrium/aorta ratio, ventricular septum in diastole, ventricular septum in systole, LVWs, LVWd, left ventricle in diastole, left ventricle in systole, ejection fraction and shortening fraction. The M-mode echocardiography evaluation of cats is impacted by the animal's body mass; therefore, the BSC must be taken into consideration when interpreting echocardiography measurements.
\end{abstract}

Keywords: cardiomyopathy, reference values, interventricular septum, left ventricular wall.

\section{Resumo}

Para determinar as medidas de referência da ecocardiografia modo-M para gatos brasileiros aleatoriamente criados no Rio de Janeiro, Brasil, os gatos que se apresentaram para tratamento de rotina foram examinados pela ecocardiografia modo-M. Animais com parede livre do ventrículo esquerdo e / ou septo interventricular acima de $5 \mathrm{~mm}$ não foram incluídos. Um total de 125 gatos foram incluídos no estudo. A correlação do escore de condição corporal (ECC) com as medidas do ecocardiograma foi positiva para parede do ventrículo esquerdo na sístole (PLVEs) e parede do ventrículo esquerdo na diástole (PLVEd). Os valores de PLVEd dos ECC 3 e 4 foram diferentes; e os dos ECC 3 e 5 também eram diferentes. Os valores de PLVEs dos ECC 3 e 5 foram diferentes. O efeito correlacionado entre a ECC e a ecocardiografia foi verdadeiro para o átrio esquerdo, relação átrio esquerdo / aorta, septo ventricular em diástole, septo ventricular em sístole, PLVEd, PLVEs, diâmetro do ventrículo esquerdo em diástole e em sístole, fração de ejeção e fração de encurtamento. A avaliação ecocardiográfica do modo $\mathrm{M}$ dos gatos é afetada pela massa corporal do animal; portanto, o ECC deve ser levado em consideração ao interpretar medidas de ecocardiografia.

Palavras-chave: cardiomiopatia, valores de referência, septo interventricular, parede ventricular esquerda.

\section{Introduction}

Echocardiography is a noninvasive exam that allows a safe morphofunctional evaluation of the heart (Boon, 2011). The M-mode is especially helpful for evaluating echogenic tissues, allowing objective measurements of the cardiac chambers, the wall thickness, and valvar movements, as well as functional index calculations, such as the shortening fraction. The Doppler analysis
How to cite: Alberigi, B. R. S., Bendas, A. J. R., Soares, D. V., Athar, C. A., Knackfuss, F. B., Demo, R. S., Almeida, M. F. S., \& Paiva, J. P. (2019). M-mode echocardiography measurements of healthy Brazilian random bred cats. Brazilian Journal of Veterinary Medicine, 41, e102919. doi: 10.29374/2527-2179.bjvm102919

Financial support: This study was financed in part by the Coordenação de Aperfeiçoamento de Pessoal de Nível Superior - Brasil (CAPES) Finance Code 001.

Conflict of interests: No conflict of interests declared concerning the publication of this article.

Received: February 16, 2019.

Accepted: May 22, 2019.

Thestudy was carried outat Hospital Veterinário, Universidade Federal Rural do Rio de Janeiro UFRRJ and Instituto de Especialidades em Medicina Veterinária, Seropédica, RJ, Brasil

\section{*Correspondence}

Bruno Ricardo Soares Alberigi da Silva Programa de Pós-graduação em Medicina Veterinária - PPGMV, Universidade Federal Rural do Rio de Janeiro - UFRRJ Rodovia BR 465, Km 07, s/n Zona Rural CEP 23890-000 - Seropédica (RJ), Brasil E-mail: bruno.alberigi@gmail.com

Copyright Alberigi et al. This is an Open Access article distributed under the terms of the Creative Commons Attribution Non-Commercial License which permits unrestricted non-commercial use, distribution, and reproduction in any medium provided the original work is properly cited. 
evaluates the velocity and pressure gradient of the blood flow inside the cardiac chambers and large vessels, as well as diastolic function (Chetboul et al., 2012; Bright, 2006). Therefore, M-mode echocardiography is the exam to detect the silent life-threatening myocardiopathies that represent the most frequent feline cardiopathy (Côté et al., 2011; Schwartz, 2003), (Tilley et al., 1977; Fox, 1999; Gundler et al., 2008).

M-mode echocardiography measurements for domestic cats have been standardized for the large breed Maine Coon (mean weight of $7.7 \mathrm{~kg}$ ) (Gundler et al., 2008). For this breed, left ventricular wall in diastole (LVWd) and ventricular septum in diastole (VSd) values above $6 \mathrm{~mm}$ are diagnostic of cardiac hypertrophy (Moise et al., 1986; Schwartz, 2003; Fox et al., 2009; Ferasin, 2009; Côté et al., 2011). For smaller cats, such as the American domestic short hair (mean weight 4.76) (include reference), the normal measurements are an LVWd of $4.6 \mathrm{~mm}$ and a VSd of $4 \mathrm{~mm}$ (Moise et al., 1986) or an LVWd of $5.5 \mathrm{~mm}$ and a VSd of $5 \mathrm{~mm}$ (Ware, 2011).

Therefore, considering the varying measurements according to the size of the animal and that Brazilian random bred cats are small and have no weight or echocardiography standards, the aim of this study was to determine M-mode echocardiography standard measurements and correlate them with the BSC in order to allow early detection of silent, life-threatening myocardiopathies.

\section{Material and methods}

This study was approved by the animal use committee CEUA-FAPUR protocol number 01-05-13. After the owners' consent, 135 cats independent of sex or age, with no history of cardiopathy, presented for routine care at the Universidade Federal Rural do Rio de Janeiro or at the Instituto de Especialidades em Medicina Veterinária, a private hospital in Rio de Janeiro, were subjected to a physical exam and echocardiography. Cats presenting with clinical signs of disease or measurements of left ventricular wall and ventricular septum, in diastole, over $5 \mathrm{~mm}$ (Ware, 2011; Häggström et al., 2016) were not included.

A total of 125 cats were included, weighed and classified according to their BSC from 1 to 5 (Edney \& Smith, 1986)

The history data capture and physical exam were performed by one operator, and the echocardiography was performed by a separate operator to maintain a blind study. The echocardiography equipment used was Esaote, model MyLab 50 Xvision cardiovascular ${ }^{\circledR}$, using two transducers (1-4 MHZ and 4-11 MHZ). The echocardiographic examination was performed without anesthesia or a tranquilizer. The cats were manually restrained by their owners and positioned on the left lateral recumbence. The echocardiogram exam was performed as proposed by Madron (2016) using the following views: left parasternal long axis, left cranial paraesternal, right ventricular outflow tract, left paraesternal apical chambers 4 and 5, and right paraesternal short axis left ventricular. The left atrium (LA), left atrium/aorta ratio (LA/AO), ventricular septum in diastole (VSd), ventricular septum in systole (VSs), left ventricular wall in diastole (LVWd), left ventricular wall in systole (LVWs), left ventricle in diastole (LVd), left ventricle in systole (LVs), shortening fraction (SF) and ejection fraction (EF) were recorded.

Based on the resampling technique by Bootstrap with 1000000 replicas, the confidence intervals (CIs) of the analyzed variables were calculated to generate reference values according to the results. Analysis of variance was performed to test the significance of each measure, and when significant, Tukey's test was used to determine the difference between the means. To test correlation, the Pearson correlation coefficient was used.

\section{Results}

Of the 125 cats included, 72 were female and 53 were male. The mean weight was $4.7+1.5 \mathrm{~kg}$ (CV 31\%), the BSC mode was 3 for 69 cats, 46 cats presented with a BSC of 4, 8 cats presented with a BSC of 5 , and 2 cats presented with a BSC of 2 . The fact that $92 \%$ of the animals presented with a BSC of 3 or 4 indicates homogeneity of the body size of the cats.

The correlation of BSC with the echocardiographic measurements was positive when LVWs $(p=0.0013)$ or LVWd ( $p=0.0009)$ was considered (Table 1). When the measurements of LVWd were compared among different BSC cats, LVWd was larger in BSC 4 cats than that in BSC 3 cats 
Table 1. Analysis of variance of the echocardiography measurements with significance levels (p).

\begin{tabular}{lcl}
\hline \multicolumn{1}{c}{ Variants } & f & p \\
\hline Left atrium & 0.2583 & 0.8564 \\
Left atrium aorta ratio & 1.0552 & 0.3523 \\
Ventricular septum in diastole & 2.4427 & 0.0892 \\
Ventricular septum in systole & 1.4138 & 0.2459 \\
Left ventricular wall in diastole & 7.9748 & 0.0009 \\
Left ventricular wall in systole & 7.3676 & 0.0013 \\
Left ventricle in diastole & 1.0372 & 0.3588 \\
Left ventricle in systole & 0.8347 & 0.5601 \\
Shortening fraction & 0.1237 & 0.9452 \\
Ejection fraction & 0.6943 & 0.5059 \\
\hline
\end{tabular}

$\mathrm{f}=$ analysis of variance.

$(\mathrm{Q}=5.05 ; \mathrm{p}<0.01)$ and was larger in $\mathrm{BSC} 5$ cats than that in $\mathrm{BSC} 3$ cats $(\mathrm{Q}=3.50 ; \mathrm{p}<0.05)$. A difference in the LVWs measurements was observed only between BSC 3 and 5 cats $(Q=5.00 ; \mathrm{p}=<0.01)$.

The systolic function of the myocardium evaluation measurements showed an LVd mean of $1.39 \mathrm{~mm} \pm 0.17$ and an LVs mean of $0.65 \pm 0.13$. The SF mean was $52.87 \pm 7.46$, and the ejection fraction mean was $85.74 \pm 7.25 \%$. These results show significant sample homogeneity with all the coefficients of variation below $20 \%$ (Table 1).

The correlated effect of the BSC and echocardiographic measurements estimated using Pearson's correlation coefficient were: $\mathrm{LA}(\mathrm{r}=-0.0347 ; \mathrm{p}=0.7008)$, LA/AO $(\mathrm{r}=-0.1341 ; \mathrm{p}=0.1358)$, IVSd $(r=0.2152 ; p=0.0159)$, IVSs $(r=0.2152 ; p=0.0159)$, LVFWs $(r=0.3403 ; \mathbf{p}=\mathbf{0 . 0 0 0 1})$, LVFWd $(r=0.3444 ; p=<0.0001), \operatorname{LVDD}(r=0.2409 ; p=0.0068), \operatorname{LVSD}(r=0.1355, p=0.1318)$, $\mathrm{EF}(\mathrm{r}=0.1318 ; \mathrm{p}=0.6711)$ and SF $(\mathrm{r}=-0.046 ; \mathrm{p}=0.6105)$.

The reference values of the M-mode echocardiography measurements are shown in Table 2.

Table 2. Proposed reference values (mm) of the M-mode echocardiography measurements for Brazilian domestic short hair cats.

\begin{tabular}{lccc}
\hline \multicolumn{1}{c}{ Variant } & Lower Limit & Mean & Upper limit \\
\hline Left atrium & 1.21 & 1.23 & 1.26 \\
Left atrium aorta ratio & 1.21 & 1.24 & 1.26 \\
Ventricular septum in diastole & 0.39 & 0.40 & 0.41 \\
Ventricular septum in systole & 0.71 & 0.73 & 0.75 \\
Left ventricular wall in diastole & 0.38 & 0.39 & 0.40 \\
Left ventricular wall in systole & 0.65 & 0.67 & 0.68 \\
Left ventricle in diastole & 1.36 & 1.39 & 1.41 \\
Left ventricle in systole & 0.63 & 0.65 & 0.67 \\
Shortening fraction & 51.68 & 52.98 & 54.09 \\
Ejection fraction & 85.28 & 86.30 & 87.15 \\
\hline
\end{tabular}

\section{Discussion}

The demonstrated positive correlation of systolic and diastolic left ventricle wall (LVW) measurements with BSC shows that cats with a higher BSC must be examined with caution, as their measurement values will tend to be larger. This suggests that the LVW tends to develop an 
adaptive concentric hypertrophy, probably because the heart needs to enhance its contraction force to maintain blood flow in a large body mass. Different from the results reported here, a previous study using allometry observed that echocardiographic measurements were influenced by body weight, mainly VSd (Karsten et al., 2017); the discrepancy between results can be due to the different methods used. Another study observed the influence of body weight on cardiac measurements, mainly in the left atrium/aorta ratio, but they did not use BSC (Häggström et al., 2016). The mean of the left atrium diameter measurements showed no difference compared with that found in other studies (Moise et al., 1986; Sisson et al., 1991).

The LA/AO ratio is the most used measurement to evaluate the left atrium size, and the normal reference value for cats is 1:7 (Boon, 2011). In the present study, the mean LA/AO ratio was $1.24 \pm$ 0.13, (c.v of 11\%) with high sample homogeneity and a somewhat smaller reference value.

Measurements were compared with those registered before (Table 3), and the differences in LA/AO, VSD, LVWd, LVWs, LVd and LVs were assigned to the studied animals' size and breed (Tilley et al., 1977; Fox, 1999, 2014; Boon, 2011; Ware, 2011; Chetboul et al., 2012).

Table 3. Echocardiography measurements (mean \pm standard deviation) of Brazilian random bred cats (BRBC).

\begin{tabular}{|c|c|c|c|c|c|c|c|c|c|c|c|}
\hline Variant & $\begin{array}{c}\text { Weight } \\
\text { (kg) }\end{array}$ & $\begin{array}{c}\text { LA } \\
(\mathrm{cm})\end{array}$ & LA/AO & $\begin{array}{l}\text { VSd } \\
(\mathrm{cm})\end{array}$ & $\begin{array}{l}\text { VSs } \\
(\mathrm{cm})\end{array}$ & $\begin{array}{l}\text { LVWd } \\
(\mathrm{cm})\end{array}$ & $\begin{array}{l}\text { LVWs } \\
(\mathrm{cm})\end{array}$ & $\begin{array}{l}\mathrm{LVd} \\
(\mathrm{cm})\end{array}$ & $\begin{array}{l}\text { LVs } \\
(\mathrm{cm})\end{array}$ & $\begin{array}{l}\text { SF } \\
(\%)\end{array}$ & $\begin{array}{l}\mathrm{EF} \\
(\%)\end{array}$ \\
\hline $\begin{array}{l}\text { BRBC } \\
N=125\end{array}$ & $4.7 \pm 1.5$ & $1.23 \pm 0.17$ & $1.24 \pm 0.13$ & $0.4 \pm 0.05$ & $0.73 \pm 0.11$ & $0.39 \pm 0.06$ & $0.67 \pm 0.11$ & $1.39 \pm 0.17$ & $0.65 \pm 0.13$ & $52.87 \pm 7.46$ & $85.74 \pm 7.25$ \\
\hline
\end{tabular}

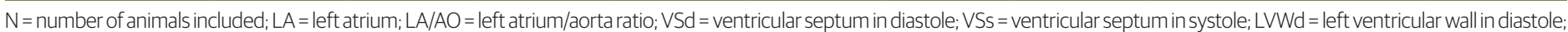
LVWs = left ventricular wall in systole; LVd = left ventricle in diastole; LVs = left ventricle in systole; $\mathrm{SF}=$ shortening fraction; $\mathrm{EF}=$ ejection fraction.

Studies that included American domestic short hair cats registered cardiac measurements similar to those presented in this study (Table 3) (Fox et al., 1985; Moise et al., 1986; Sisson et al., 1991; Häggström et al., 2016), indicating that breed and therefore size range plays an important role in reference values. When analyzing different studies measurements it must be considered that many studies included sedated cats (Fox et al., 1985) or sampled only a small number if cats (Fox et al., 1985; Moise et al., 1986; Sisson et al., 1991). A large sampling was performed, but the authors did not list breeds or BSC they included (Häggström et al., 2016) Reference values of VSd and LVWd were stablished using Maine Coon and Ragdoll, two large breeds, with no attention to the body mass that impacts on the size of the heart, therefore the reference was settled below 6 mm (Côté et al., 2011; Schwartz, 2003; Fox et al., 2009; Ferasin, 2009). Since the Brazilian random bred cats included in this study were smaller, the LVWd and VSd measurements were also smaller (Table 2).

In the present study, the mean $\mathrm{EF}$ was $85.74 \% \pm 7.25$ (c.V 8\%). In most reports, the $\mathrm{EF}$ was not determined (Fox et al., 1985; Moise et al., 1986; Sisson et al., 1991), and there is no reference value established for adult cats (Moise et al., 1986; Sisson et al., 1991; Branquinho et al., 2010; Boon, 2011; Côté et al., 2011; Häggström et al., 2016); however, for growing kittens from two to 11 weeks of age, the reference EF measurement ranged from 61\% to 87\% (Schille \& Skrodzki, 1999). According to Morcef (2001), a subjective analysis performed by an experienced echocardiographer is the best EF evaluation; however, an objective parameter can avoid biases and help less experienced echocardiographers to properly evaluate EF.

\section{Conclusions}

The M-mode echocardiography evaluation of cats is impacted by the animal's body mass; therefore, the BSC must be taken into consideration when interpreting echocardiography measurements. Since Brazilian random bred cats and breeds or local varieties in other countries are smaller than most breeds used for establishing reference measurements, further studies must be conducted to determine the reference measurements for different breeds.

\section{Acknowledgements}

To Professor Norma Labarthe (FIOCRUZ-RJ, Brazil) for the collaboration in the study 


\section{References}

Boon, J. A. (2011). Myocardial diseases. In J. A. Boon (Ed.), Veterinary echocardiography (2nd ed., pp. 359-410). West Sussex: Wiley-Blackel.

Branquinho, J., Monzo, M., Cláudio, J. L. M. D., Rosado, M., Carvalho, J. L., Lacerda, R., \& Rodrigues, K. (2010). Diagnóstico imagiológico de cardiomiopatia hipertrófica. Revista Lusófona de Ciência e Medicina Veterinária, 3, 36-44.

Bright, J. (2006). Cardiomiopatia hipertrófica felina. In J. A. Abbot (Ed.), Segredos em cardiologia de pequenos animais (1a ed., pp. 321-333). Porto Alegre: Art Med.

Chetboul, V., Petit, A., Gouni, V., Trehiou-Sechi, E., Misbach, C., Balouka, D., Sampedrano, C. C., Pouchelon, J.-L., Tissier, R., \& Abitbol, M. (2012). Prospective echocardiographic and tissue Doppler screenin of large sphynx cat population: reference ranges, heart disease prevalence and genetic aspects. Journal of Veterinary Cardiology, 14(4), 497-509. http://dx.doi.org/10.1016/j.jvc.2012.08.001. PMid:23131204.

Côté, E., MacDonald, K. A., Meurs, K. M., \& Sleeper, M. M. (2011). Hypertrophic cardiomyopathy. In E. Côté, K. A. MacDonald, K. M. Meurs \& M. M. Sleeper (Eds.), Feline cardiology (1st ed., pp. 103-175). West Sussex: WileyBlackel. http://dx.doi.org/10.1002/9781118785782.

Edney, A. T., \& Smith, P. (1986). Study of obesity in dogs visiting veterinary practices in the United Kingdom. The Veterinary Record, 118(14), 391-396. http://dx.doi.org/10.1136/vr.118.14.391. PMid:3716092.

Ferasin, L. (2009). Feline myocardial disease 2: diagnosis, prognosis and clinical management. Journal of Feline Medicine and Surgery, 11(3), 183-194. http://dx.doi.org/10.1016/j.jfms.2009.01.002. PMid:19237134.

Fox, P. R. (1999). Feline myocardial diseases. In P. R. Fox, D. D. Sisson \& S. N. Moise (Eds.), Textbook of canine and feline cardiology principles and practice (2nd ed., pp. 621-678). Philadelphia: WB Saunders.

Fox, P. R. (2014). Feline cardiomyopathy. In Proceedings of the WINN Symposium. New York: WINN. Retrieved in 2019, February 16, from http://www.winnfelinefoundation.org/

Fox, P. R., Bond, B. R., \& Peterson, M. E. (1985). Echocardiographic reference values in healthy cats sedated with ketamine hydrochloride. American Journal of Veterinary Research, 46(7), 1479-1484. PMid:4026030.

Fox, P. R., Oyama, M. A., Reynolds, C., Rush, J. E., DeFrancesco, T. C., Keene, B. W., Atkins, C. E., MacDonald, K. A., Schober, K. E., Bonagura, J. D., Stepien, R. L., Kellihan, H. B., Nguyenba, T. P., Lehmkuhl, L. B., Lefbom, B. K., Moise, N. S., \& Hogan, D. F. (2009). Utility of plasma N-terminal pro-brain natriuretic peptide (NT-proBNP) to distinguish between congestive heart failure and non-cardiac causes of acute dyspnea in cats. Journal of Veterinary Cardiology, 11(Suppl 1), 51-61. http://dx.doi.org/10.1016/j.jvc.2008.12.001. PMid:19394287.

Gundler, S., Tidholm, A., \& Häggström, J. (2008). Prevalence of myocardial hypertrophy in a population of asymptomatic Swedish Mainecoon cats. Acta Veterinaria Scandinavica, 50(1), 22. http://dx.doi.org/10.1186/17510147-50-22. PMid:18564408.

Häggström, J., Andersson, Å. O., Falk, T., Nilsfors, L., OIsson, U., Kresken, J. G., Höglund, K., Rishniw, M., Tidholm, A., \& Ljungvall, I. (2016). Effect of body weight on echocardiographic measurements in 19,866 pure-bred cats with or without heart disease. Journal of Veterinary Internal Medicine, 30(5), 1601-1611. http://dx.doi. org/10.1111/jvim.14569. PMid:27573384.

Karsten, S., Stephanie, S., \& Vedat, Y. (2017). Reference intervals and allometric caling of two-dimensional echocardiographic measurements in 150 healthy cats. The Journal of Veterinary Medical Science, 79(11), 1764-1771. http://dx.doi.org/10.1292/jvms.17-0250. PMid:28993567.

Madron, E. (2016). Normal view a: 2D, TM, spectral, and color Doppler. In V. Chetboul, C. Bussadori \& E. Madron (Eds.), Clinical echocardiography of the dog and cat (1st ed., pp. 3-19). Missouri: Elsevier.

Moise, N. S., Dietze, A. E., Mezza, L. E., Strickland, D., Erb, H. N., \& Edwards, N. J. (1986). Echocardiography, electrocardiography, and radiography of cats with dilatation cardiomyopathy, hypertrophic cardiomyopathy, and hyperthyroidism. American Journal of Veterinary Research, 47(7), 1476-1486. PMid:2943198.

Morcef, F. A. P. (2001). Avaliação do tamanho e função do ventrículo esquerdo. In F. A. Morcef(Ed.), Ecocardiografia uni-bidimensional, transesofágica e Doppler (2a ed., pp. 193-225). Rio de Janeiro: Revinter.

Schille, S., \& Skrodzki, M. (1999). M-mode echocardiographic reference values in cats in the first three months of life. Veterinary Radiology \& Ultrasound, 40(5), 491-500. http://dx.doi.org/10.1111/j.1740-8261.1999.tb00381.x. PMid:10528844.

Schwartz, D. (2003). Cardiomiopatia hipertrófica. In J. H. Moreira (Ed.), Coletâneas em medicina e cirugia felina (1a ed., pp. 25-41). Rio de Janeiro: LF Livros.

Sisson, D. D., Knight, D. H., Helinski, C., Fox, P. R., Bond, B. R., Harpster, N. K., Moise, N. S., Kaplan, P. M., Bonagura, J. D., Czarnecki, G., \& Schaeffer, D. J. (1991). Plasma taurine concentrations and M-mode echocardiographic measures in healthy cats and in cats with dilated cardiomyopathy. Journal of Veterinary Internal Medicine, 5(4), 232-238. http://dx.doi.org/10.1111/j.1939-1676.1991.tb00954.x. PMid:1941757.

Tilley, L. P., Liu, S. K., Gilbertson, S. R., Wagner, B. M., \& Lord, P. F. (1977). Primary myocardial disease in the cat: a model for human cardiomyopathy. American Journal of Pathology, 86(3), 493-522. PMid:842611.

Ware, W. E. (2011). Myocardial disease of the cat. In W. Ware(Ed.), Cardiovascular disease in small animal medicine (2nd ed., pp. 300-310). London: Manson Publishing. http://dx.doi.org/10.1201/b15177-25. 